\title{
Comparison of three-dimensional and two-dimensional quantitative coronary analysis measuring intracoronary lengths in patients undergoing diagnostic coronary angiography
}

Porównanie trójwymiarowej i dwuwymiarowej analizy ilościowej tętnic wieńcowych w odniesieniu do pomiaru długości segmentów wieńcowych u pacjentów poddawanych diagnostycznej koronarografii

Jacek Legutko', Lukasz Rzeszutko', Lukasz Partyka ${ }^{1,2}$, Rafał Depukatt, Marcin Wojdyla', Grzegorz Barycz, ${ }^{1}$, Marcin Wizimirski ${ }^{1,2}$, Justyna Stefaniak², Folkert Tijdens ${ }^{3}$, Lizet Bary ${ }^{3}$, Jacek S. Dubiel', Dariusz Dudek ${ }^{1}$, Grzegorz L Kaluza ${ }^{4}$

${ }_{12}{ }^{\text {nd }}$ Department of Cardiology, Jagiellonian University Medical College, Krakow, Poland

2Krakow Cardiovascular Research Institute, Poland

3Pie Medical Imaging, Maastricht, the Netherlands

${ }^{4}$ Cardiovascular Research Foundation, The Jack H. Skirball Center for Cardiovascular Research, New York, USA

Post Kardiol Interw 2012; 8, 1 (27): 31-41

DOI: $10.5114 /$ pwki.2012.27923

\section{Abstract}

Aim: To determine if three-dimensional quantitative coronary angiographic analysis (3D QCA) provides an advantage over twodimensional (2D QCA) by increasing accuracy and precision of length measurements through compensating for foreshortening inherent to 2D images.

Material and methods: A total of 800 inter-marker length measurements were performed (8 per wire, 5-40 mm) with novel 3D software and standard 2D software and compared with the true lengths of the inter-marker distances on the wire in coronary vessels of 21 patients recruited.

Results: 2D QCA generally underestimated true length in comparison to 3D, and the discrepancy increased with absolute length. In contrast, 3D QCA showed a minimal difference from true length over the examined range of lengths.

Conclusions: 3D QCA minimizes errors in length measurements associated with foreshortening, shows minimal difference from true length, and performs significantly better in comparison to 2D QCA. The advantage of 3D QCA is more pronounced at longer lengths.

Key words: 3D, 2D, quantitative coronary angiography (QCA)

Streszczenie

Cel: Określenie, czy trójwymiarowa, ilościowa analiza angiograficzna naczyń wieńcowych (3D QCA) ma przewagę nad standardową oceną dwuwymiarową (2D QCA) polegającą na zwiększeniu dokładności i precyzji pomiarów długości oraz wyeliminowaniu skrócenia typowego dla analiz 2D.

Materiał i metody: Wykonano ogółem 800 pomiarów długości odcinka pomiędzy markerami na prowadnikach wieńcowych wprowadzonych do tętnicy wieńcowej (8 długości na prowadniku w zakresie 5-40 mm) z zastosowaniem oprogramowania 3D i standardowego oprogramowania 2D w porównaniu ze znanymi odległościami znaczników na prowadniku wieńcowym u 21 pacjentów poddanych koronarografii.

Wyniki: W analizie 2D QCA pomiary były z reguły zaniżone w stosunku do rzeczywistej długości mierzonego odcinka, przy czym wielkość błędu wzrastała wraz z bezwzględną długością mierzonego odcinka. Analizy za pomocą 3D QCA wykazały minimalne różnice pomiarów w stosunku do rzeczywistych odległości pomiędzy markerami w całym zakresie badanych długości.

Corresponding author/Adres do korespondencji:

Jacek Legutko MD, PhD, $2^{\text {nd }}$ Department of Cardiology, Jagiellonian University Medical College, 17 Kopernika, 31-501 Krakow, Poland, tel.: +48 1242471 81, fax: +48 1242471 84, e-mail: jlegutko@kcri.org

Praca wptynęła: 6.02.2012, przyjęta do druku: 5.03.2012. 
Wnioski: Technika 3D QCA minimalizuje błędy pomiarów długości związane z artefaktem skrócenia obrazowego obiektu (foreshortening) typowego dla 2D QCA wykazuje minimalne odstępstwa od rzeczywistych długości w stosunku do analiz 2D QCA. 3D QCA ma szczególną przewagę w przypadku większych długości.

Słowa kluczowe: 3D, 2D, ilościowa angiografia wieńcowa (QCA)

\section{Background}

Two-dimensional (2D) quantitative coronary analysis (QCA) is routinely applied to provide an objective characterization of coronary lesions [1]. Reference diameter and lesion length are key parameters for determining the appropriate stent size for the lesion of interest. Although 2D QCA has been well validated in phantoms and its reproducibility is well established, foreshortening of the arterial segment of interest in a two-dimensional image continues to be a significant problem when determining lesion length, eccentricity, and tortuosity [2, 3]. Due to these limitations, coronary angiography modeling using threedimensional QCA on the basis of images and structures visualized and captured during standard and rotational angiography was introduced $[4,5]$ and is currently being evaluated for its utility in clinical practice [6-10].

CAAS 3D QCA is a novel, FDA-approved software (Pie Medical Imaging, Maastricht, Netherlands) utilizing 2D angiographic images to construct three-dimensional renderings of coronary arterial anatomy that improve the visualization of tortuous segments, bifurcations and eccentricity. The software has standard QCA functionality, providing information regarding the stenotic lesion, such as percentage of luminal narrowing, length and eccentricity of the lesion. It may provide accurate measurements of intracoronary lengths and 3D mapping of the coronary arteries, facilitating visualization of vessel curvature, elimination of foreshortening and measurement of vessel length $[4,11]$. This has been increasingly important in the drug-eluting stent era, when appropriate coverage of lesion with the stent is imperative to avoid edge restenosis [12], as well as to decrease the risk of stent thrombosis, which was found to correlate with stent length [13-17].

\section{Aim}

The aim of the present study was to assess the utility of 3D QCA modeling in vivo by evaluation of the intracoronary length measurements in human coronary anatomy. To that end, in patients undergoing diagnostic coronary angiography, a guidewire with markers was introduced into coronary arteries and the distances between multiple markers were measured with 2D QCA and 3D QCA, and compared to actual inter-marker distances on the wires.

\section{Material and methods}

\section{Study population and design}

The study was approved by the Institutional Review Board of the Jagiellonian University (Krakow, Poland) and each patient provided written informed consent. The study population consisted of 21 consecutive patients admitted to the Department of Hemodynamics and Angiocardiography of University Hospital (Krakow, Poland) for coronary intervention. There were no eligibility criteria for patients to have their images considered for study analysis.

During the coronary angiography procedure, a marker guide wire (IQ Guide Wire, Boston Scientific, Natick, MA, USA) was inserted into the coronary artery. Then, study angiograms were obtained with the mixture of the contrast media half to half with saline for good visualization of the wire radiopaque markers in the coronary artery. The IQ wire is a guide wire with 3 radiopaque markers, two $5 \mathrm{~mm}$ long, separated by two $15 \mathrm{~mm}$ long distances and the longest $20 \mathrm{~mm}$ distal marker. Combination of markers' lengths with inter-marker distances rendered 8 different lengths per vessel (ranging from $5 \mathrm{~mm}$ to $40 \mathrm{~mm}$ ) that could be measured offline by the QCA software (Figure 1). The marker wire did not interfere with contour detection of the QCA software.

Angiograms were recorded with flat panel monoplane $\mathrm{X}$-ray systems. Monoplane projections were acquired with at least 30 degrees apart in both planes (cranial-caudal and left-right) for each vessel of interest and no table or patient movement between and during the recordings. Images were acquired during breath hold and in both projections the segment of interest was clearly visible and had minimal overlap. Electrocardiogram (ECG) data recording was present in the recorded images.

\section{Analysis method}

Angiograms complying with the eligibility criteria were transferred to the core laboratory for analysis (Krakow Cardiovascular Research Institute, KCRI, Krakow, Poland). In total, 50 coronary marker wires were visualized by angiography. 3D quantitative analyses were performed by a trained analyst experienced in the use of the CAAS analytical software. Off-line QCA analysis was performed with standard 2D QCA software (CAAS II, Pie Medical, Maastricht, Netherlands) for both projections using a known catheter size for calibration in accordance with established standard QCA methodology. The same 2 angiographic frames were used for $3 \mathrm{D}$ reconstruction using the research version of the 3D QCA software (CAAS 3D version 5.2). In contrast to commercially available 3D QCA software, which renders only one set of measurements for each reconstructed segment, the research version of CAAS 3D QCA permitted length measurements in two projections, so each length measured in 3D had a corresponding length for comparison derived from the same projection in $2 \mathrm{D}$ 
QCA, allowing precise head-to-head comparisons between 2 methods.

As such, 800 single measurements of length with 2D were performed and the same number (800) of measurements using 3D QCA for comparisons. For intra- and interobserver variability, 80 additional measurements were repeated using both methods by the same analyst and by a second analyst, respectively.

The differences between various lengths of markers and distances separating the markers on the guide wire as measured in 3D angiography and standard 2D QCA compared to the corresponding actual distances on the wire (true lengths) were analyzed. Analyses of 5 (10\%) randomly selected arteries were also repeated by the same analyst to evaluate intra-observer variability as well as by the second analyst to evaluate the inter-observer variability.

\section{Software description}

The CAAS QCA 3D system combines information from biplane or multiple monoplane images to calculate a 3D reconstruction and perform quantitative analysis on the vessel part of interest (Figure 2). The differences in angulation between the projections used should be at least 30 degrees. The user performs a semi-automatic 2D contour detection based on the Minimum Cost Algorithm described previously $[18,19]$; this step needs to be performed in both projections. A Common Image Point (CIP) is automatically placed at a similar position in both projections and its position can be adjusted by the user. The algorithm then performs a 3D reconstruction from which length, diameters and cross-sectional areas can be derived.

\section{Statistical analysis}

Angiograms of 50 individual arteries were included in the registry. For continuous variables (differences in length measurements), the data were presented as mean, standard deviation, median, skewness, minimum, maximum and number of observations. These continuous data were compared using Wilcoxon signed-rank test for two groups. No formal power calculation has been performed, as this was an observational registry. Box-and-whisker plots were produced.

We defined measurement errors as difference between true and measured inter-marker lengths and reported them across the entire range of lengths evaluated $(5 \mathrm{~mm}$ to $40 \mathrm{~mm}$ ). We also defined significant error as one exceeding $10 \%$ of true length, according to the formula: (measurement - true length) $\geq$ (true length)/10. We then reported the frequency of such significant errors in percentages for all lengths and compared these frequencies between 2D QCA and 3D QCA using the $\chi^{2}$ test.

All statistical analysis were performed using the SPSS software (15.0, SPSS, Chicago, IL, USA). A $p$ value $<0.05$ was considered statistically significant.
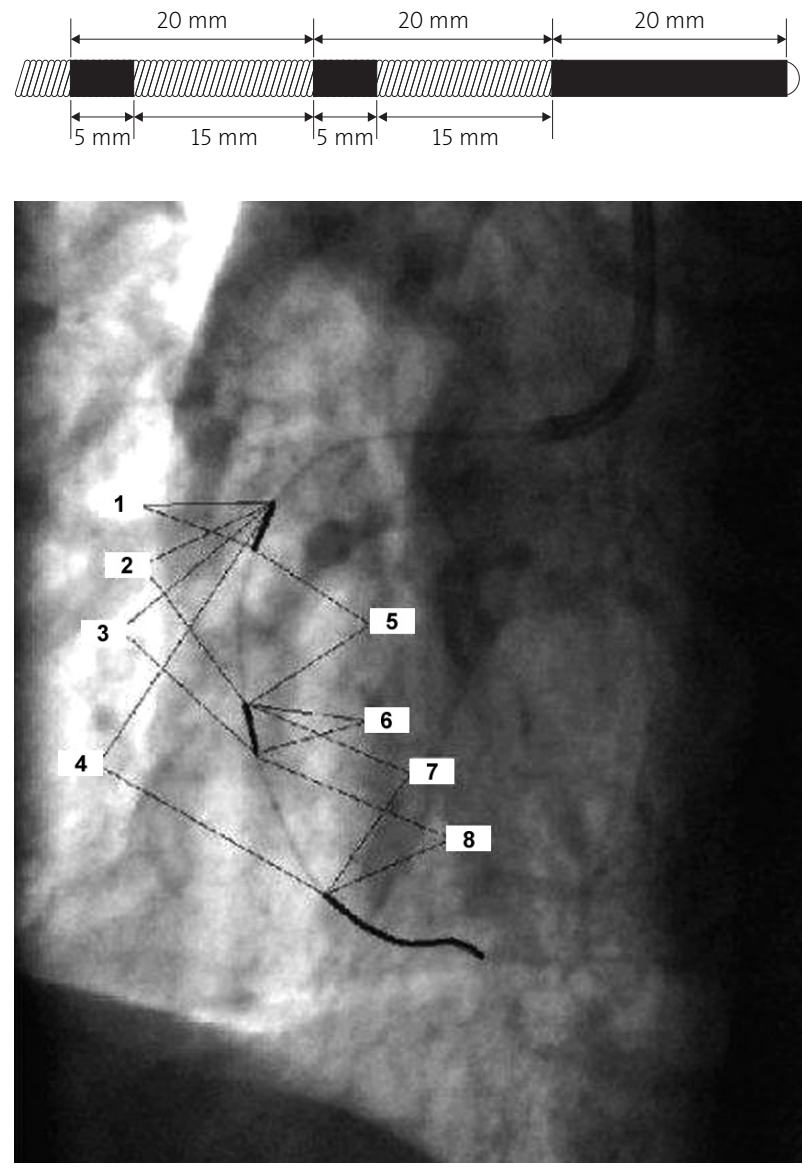

Fig. 1. Marker wire and lengths used for measurements in 2D and 3D QCA. Lengths: $5 \mathrm{~mm}$ - doubled measurement (segments on the wire: 1,6 ), $15 \mathrm{~mm}$ - doubled measurement (segments on the wire: 5, 8), $20 \mathrm{~mm}$ - doubled measurement (segments on the wire: 2, 7), $25 \mathrm{~mm}$ - proximal $20 \mathrm{~mm}$ plus mid marker (segment on the wire: 3), $40 \mathrm{~mm}$ - from distal marker to proximal marker (segment on the wire: 4)

Ryc. 1. Prowadnik wieńcowy ze znacznikami wraz z segmentami pomiędzy znacznikami, których użyto do pomiarów w 2D i 3D QCA. Długości: $5 \mathrm{~mm}$ (pomiar segmentów prowadnika: 1, 6), $15 \mathrm{~mm}$ (pomiar segmentów prowadnika: 5, 8), $20 \mathrm{~mm}$ (pomiar segmentów prowadnika: 2, 7), $25 \mathrm{~mm}$ początkowe $20 \mathrm{~mm}$ prowadnika plus środkowy marker (segment prowadnika 3), $40 \mathrm{~mm}$ - od dalszego do bliższego markera (segment 4)

\section{Results}

We enrolled 21 patients in whom 50 arteries were visualized according to the protocol. No complications occurred during any of the procedures. We obtained 20 angiograms of the left anterior descending (LAD) coronary artery, 17 of the left circumflex $(C X)$ and 13 of the right coronary artery (RCA). 


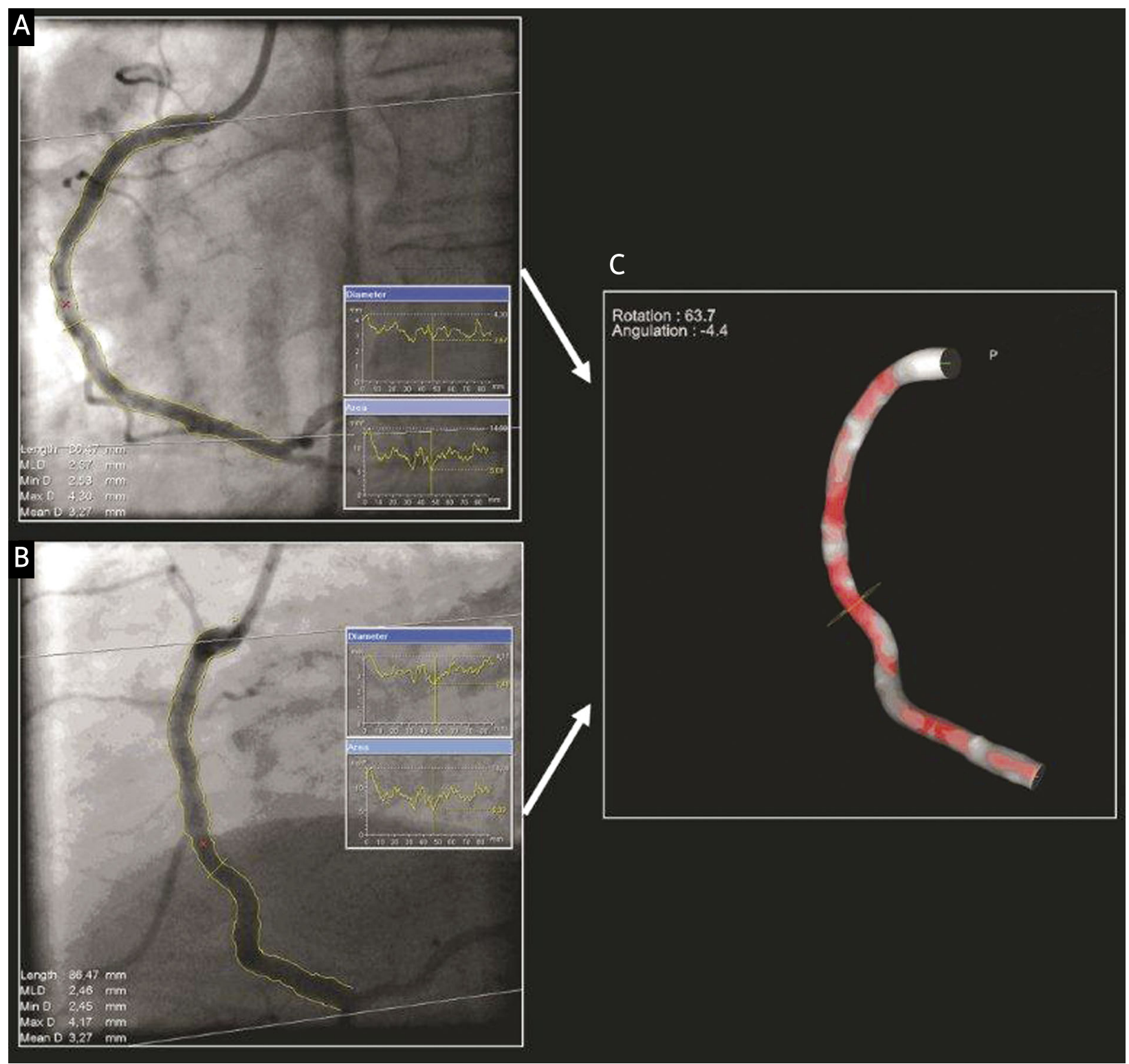

Fig. 2. 3D reconstruction $(C)$ based on $2 D$ angiographic projections ( $A$ and $B$ ). The red cross in image $A$ and $B$ is the Common Image Point. For details, see text

Ryc. 2. Rekonstrukcja 3D (C) na podstawie projekcji angiograficznych 2D (A i B). Czerwony znacznik na projekcjach A i $B$ to tzw. punkt wspólny. Szczegółowe informacje - patrz tekst

In 2D QCA, the Wilcoxon signed-rank test showed for all lengths significant differences between true and measured results ( $p<0.001)$. For 3D QCA only the $5 \mathrm{~mm}$ measured length was found insignificantly different from the true one $(p=0.55)$. However, it was evident that the mean error by 3D QCA was rather small and varied little among the measured lengths of the marker wire, ranging from $0.06 \pm 0.86 \mathrm{~mm}$ for $5 \mathrm{~mm}$ (minimum) distances on the wire to $0.79 \pm 2.06 \mathrm{~mm}$ for $40 \mathrm{~mm}$ (maximum) distances. In contrast, the mean difference between lengths measured by 2D QCA and the true lengths on the marker wire was much higher than by 3D QCA and appeared to increase proportionately to the absolute length (ranging from -0.55 $\pm 0.73 \mathrm{~mm}$ for $5 \mathrm{~mm}$ distances on the wire to -4.66 $\pm 5.21 \mathrm{~mm}$ for $40 \mathrm{~mm}$ ) (Table 1).

In 3D QCA the differences between actual and measured lengths generally had positive values attesting to a slight overestimation of length by 3D QCA compared to the true length between markers on the catheter. However, the differences barely increased with increasing absolute true length. Conversely, in 2D QCA consistently negative values of mean error between measured and actual length demonstrated repetitive underestimation of the actual intracoronary length. The errors of the 2D QCA also appeared aggravated with increasing absolute length. Both these adverse trends in 2D QCA appear to be a logical con- 
Table 1. Differences between true marker/wire lengths and those measured by 2D QCA and 3D QCA

Tabela 1. Różnice między prawdziwymi odległościami pomiędzy znacznikami na prowadniku a długościami mierzonymi za pośrednictwem 2D QCA i 3D QCA

\begin{tabular}{|c|c|c|c|c|c|c|c|c|}
\hline D & Length [mm] & Number & Mean & Standard deviation & Median & Skewness & Minimum & Maximum \\
\hline \multirow[t]{5}{*}{ 2D QCA } & 5 & 200 & -0.55 & 0.73 & -0.45 & 0.70 & -1.14 & 2.89 \\
\hline & 15 & 200 & -1.73 & 2.45 & -0.94 & 1.05 & -2.43 & 9.43 \\
\hline & 20 & 200 & -2.33 & 2.96 & -1.40 & 1.09 & -3.37 & 12.55 \\
\hline & 25 & 100 & -2.79 & 3.37 & -1.64 & 0.96 & -1.88 & 11.96 \\
\hline & 40 & 100 & -4.66 & 5.21 & -3.00 & 1.04 & -3.02 & 21.07 \\
\hline \multirow[t]{5}{*}{ 3D QCA } & 5 & 200 & 0.06 & 0.86 & -0.02 & -4.60 & -7.29 & 1.49 \\
\hline & 15 & 200 & 0.34 & 1.67 & 0.27 & -0.78 & -11.82 & 8.51 \\
\hline & 20 & 200 & 0.35 & 2.10 & 0.29 & -2.78 & -18.77 & 9.08 \\
\hline & 25 & 100 & 0.57 & 2.37 & 0.22 & -4.40 & -18.56 & 6.17 \\
\hline & 40 & 100 & 0.79 & 2.06 & 0.54 & -1.07 & -9.68 & 3.78 \\
\hline
\end{tabular}

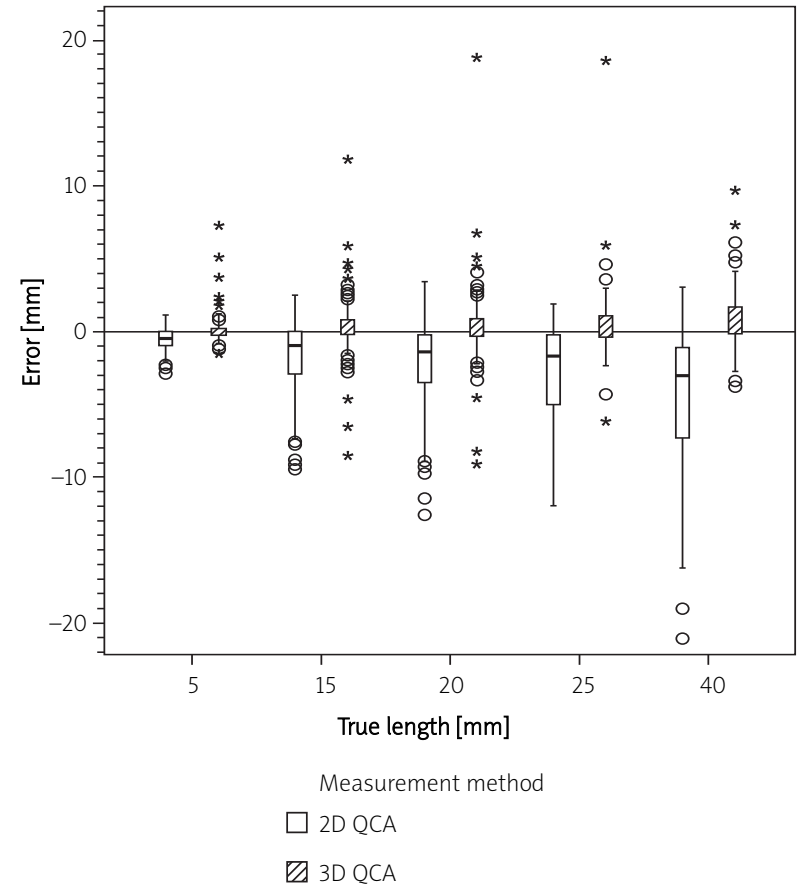

Fig. 3. Box-whisker plot illustrating differences between measurements and true length in 2D QCA vs. 3D QCA. Horizontal line denotes median value, the height of the box represents the interquartile (25\% to $75 \%$ ) range, and vertical bars show standard deviations. Outliers are shown in circles (values exceeding median $\pm 1.5 \mathrm{SD}$ ) or asterisks (values exceeding median by more than $3 \mathrm{SD}$ )

Ryc. 3. Wykres ilustrujący różnice pomiędzy prawdziwymi długościami odcinków a wartościami mierzonymi w 2D QCA vs 3D QCA. Pozioma linia oznacza średniq wartość, wysokość pudetka reprezentuje przedziat międzykwartylowy (od 25\% do 75\%), a pionowe linie pokazuja wartość odchylenia standardowego (SD). Wartości oddalone są wyświetlane jako kótka (wartości powyżej mediany \pm 1,5 SD) lub gwiazdki (wartości powyżej mediany o więcej niż 3SD) sequence of foreshortening inherent to standard 2D QCA (Figure 3), whereas the 3D QCA seems to effectively correct for this shortcoming.

This was corroborated by the analysis of error incidence. Overall, for all measurements taken, in the 2D QCA the percentage of errors exceeding $10 \%$ of true lengths was $43.5 \%$, whereas for 3D QCA it was only $15.8 \%$ $(p<0.005)$. This held true for every measured length separately as much as for all measurements pooled (Table 2). Importantly, the findings reported for the entire dataset were also valid when assessed for each coronary artery separately (Figure 4). The frequency of $10 \%$ errors in the 3D QCA was significantly lower than in the 2D QCA for all measurements made in the LAD, as well as in the RCA and LCX (Table 3). Interestingly, when only LAD was analyzed, the precision of the 3D QCA was so high that the differ-

Table 2. The number (percentage) of results with measurement error exceeding 10\% (according to the formula: |error $\mid \geq$ (true length)/10)

Tabela 2. Liczba (odsetek) wyników z błędem pomiaru przekraczającym 10\% (zgodnie z formuta: |błąd| $\geq$ (prawdziwa długość)/10)

\begin{tabular}{lcccc} 
Length [mm] & Number & 2D QCA & 3D QCA & Value of $p$ \\
\cline { 2 - 4 } & & \multicolumn{2}{c}{ |error| $\geq$ (true length) $/ 10$} & \\
\hline 5 & 200 & 102 & 47 & 0.004 \\
& & $51.0 \%$ & $23.5 \%$ & \\
\hline 15 & 200 & 86 & 35 & 0.005 \\
& & $43.0 \%$ & $17.5 \%$ & \\
\hline 20 & 200 & 81 & 28 & 0.003 \\
& & $40.5 \%$ & $14.0 \%$ & \\
\hline 25 & 100 & 38 & 10 & 0.020 \\
& & $38.0 \%$ & $10.0 \%$ & \\
\hline 40 & 100 & 41 & 6 & 0.003 \\
& & $41.0 \%$ & $6.0 \%$ & \\
\hline Overall & 800 & 348 & 126 & $<0.001$ \\
& & $43.5 \%$ & $15.8 \%$ & \\
& & &
\end{tabular}


ence between measured and actual length became insignificant (Table 4).

Errors found in the database of more than $10 \%$ of the true length in 3D QCA were scrutinized individually for possible reasons. The scrutiny revealed that a vast majority of the large errors could be explained by one of 3 reasons, and these reasons proved manageable by further software iterations. First, in rare instances, the 2D projections available for 3D reconstruction featured the socalled "blind spot". In these cases the portion of the imaged vessel where the information derived from available 2D images was insufficient (due to extreme tortuosity and/or foreshortening and/or overlapping branches) to generate unequivocal 3D reconstructions. In such instances, the system has to build this part of the reconstruction based on extrapolation and assumption, increasing the likelihood of error in these areas. In later versions of the software this was improved and reanalysis of select data with CAAS version 5.7.1 also demonstrated marked improvement of length measurement accuracy in these

Table 3. The number and percentage of results with measurement error exceeding $10 \%$ (according to the formula: |error| $\geq$ (true length)/10) calculated for each of the coronary arteries separately

Tabela 3. Liczba i odsetek wyników z błędem pomiaru przekraczającym 10\% (według wzoru: |bład| $\geq$ (prawdziwa długość)/10) przedstawione dla każdej z tętnic wieńcowych oddzielnie

\begin{tabular}{|c|c|c|c|c|c|c|c|c|c|c|c|c|}
\hline \multirow{3}{*}{$\begin{array}{l}\text { Length } \\
{[\mathrm{mm}]}\end{array}$} & \multicolumn{4}{|c|}{$C x$} & \multicolumn{4}{|c|}{ LAD } & \multicolumn{4}{|c|}{ RCA } \\
\hline & \multirow{2}{*}{ Number } & \multirow{2}{*}{\multicolumn{2}{|c|}{$\begin{array}{c}\text { 2D QCA 3D QCA } \\
\mid \text { Error } \mid \geq \\
\text { (true length) } / 10\end{array}$}} & \multirow[t]{2}{*}{ Value of $p$} & \multirow[t]{2}{*}{ Number } & \multirow{2}{*}{\multicolumn{2}{|c|}{$\begin{array}{c}\text { 2D QCA 3D QCA } \\
\mid \text { Error } \mid \geq \\
\text { (true length)/10 }\end{array}$}} & \multirow[t]{2}{*}{ Value of $p$} & \multirow[t]{2}{*}{ Number } & \multirow{2}{*}{\multicolumn{2}{|c|}{$\begin{array}{c}\text { 2D QCA 3D QCA } \\
\mid \text { Error } \mid \geq \\
\text { (true length) } / 10\end{array}$}} & \multirow[t]{2}{*}{ Value of $p$} \\
\hline & & & & & & & & & & & & \\
\hline 5 & 68 & $\begin{array}{c}32 \\
47.1 \%\end{array}$ & $\begin{array}{c}17 \\
25.0 \%\end{array}$ & NS & 80 & $\begin{array}{c}50 \\
62.5 \%\end{array}$ & $\begin{array}{c}19 \\
23.8 \%\end{array}$ & 0.014 & 52 & $\begin{array}{c}20 \\
38.5 \%\end{array}$ & $\begin{array}{c}11 \\
21.2 \%\end{array}$ & NS \\
\hline 15 & 68 & $\begin{array}{c}20 \\
29.4 \%\end{array}$ & $\begin{array}{c}13 \\
19.1 \%\end{array}$ & NS & 80 & $\begin{array}{c}43 \\
53.8 \%\end{array}$ & $\begin{array}{c}15 \\
18.8 \%\end{array}$ & 0.021 & 52 & $\begin{array}{c}23 \\
44.2 \%\end{array}$ & $\begin{array}{c}7 \\
13.5 \%\end{array}$ & NS \\
\hline 20 & 68 & $\begin{array}{c}19 \\
27.9 \%\end{array}$ & $\begin{array}{c}11 \\
16.2 \%\end{array}$ & NS & 80 & $\begin{array}{c}46 \\
57.5 \%\end{array}$ & $\begin{array}{c}11 \\
13.8 \%\end{array}$ & 0.004 & 52 & $\begin{array}{c}16 \\
30.8 \%\end{array}$ & $\begin{array}{c}6 \\
11.5 \%\end{array}$ & NS \\
\hline 25 & 34 & $\begin{array}{c}9 \\
26.5 \%\end{array}$ & $\begin{array}{c}4 \\
11.8 \%\end{array}$ & NS & 40 & $\begin{array}{c}21 \\
52.50 \%\end{array}$ & $\begin{array}{c}4 \\
10.00 \%\end{array}$ & 0.039 & 26 & $\begin{array}{c}8 \\
30.8 \%\end{array}$ & $\begin{array}{c}2 \\
7.7 \%\end{array}$ & NS \\
\hline 40 & 34 & $\begin{array}{c}9 \\
26.5 \%\end{array}$ & $\begin{array}{c}2 \\
5.9 \%\end{array}$ & NS & 40 & $\begin{array}{c}24 \\
60.0 \%\end{array}$ & $\begin{array}{c}3 \\
7.5 \%\end{array}$ & 0.013 & 26 & $\begin{array}{c}8 \\
30.8 \%\end{array}$ & $\begin{array}{c}1 \\
3.8 \%\end{array}$ & NS \\
\hline All & 272 & $\begin{array}{c}89 \\
32.7 \%\end{array}$ & $\begin{array}{c}47 \\
17.3 \%\end{array}$ & 0.038 & 320 & $\begin{array}{c}184 \\
57.5 \%\end{array}$ & $\begin{array}{c}52 \\
16.3 \%\end{array}$ & $<0.001$ & 208 & $\begin{array}{c}75 \\
36.1 \%\end{array}$ & $\begin{array}{c}27 \\
13.0 \%\end{array}$ & 0.006 \\
\hline
\end{tabular}

NS - not significant

Table 4. Statistical significance of the differences between true inter-marker length and the length measured by 2D QCA and 3D QCA calculated for every assessed length and each of the 3 investigated coronary arteries $(L A D, C x, R C A)$. For 2D QCA, all differences between true and measured lengths are significant. For 3D QCA, none of the differences for the LAD was significant

Tabela 4. Istotność statystyczna różnic pomiędzy prawdziwą długością odcinka między znacznikami a długością mierzona w 2D QCA i 3D QCA, obliczona dla każdej ocenianej długości i każdej z 3 badanych tętnic wieńcowych ( $L A D, C X, R C A)$. Dla 2D QCA wszystkie różnice pomiędzy prawdziwą a mierzona długością są istotne statystycznie.

Dla 3D QCA nie stwierdzono różnic statystycznych w wartości pomiarów w LAD

\begin{tabular}{|c|c|c|c|c|c|c|c|}
\hline D & $\begin{array}{l}\text { Length } \\
{[\mathrm{mm}]}\end{array}$ & $N$ & $\begin{array}{l}\text { Wilcoxon signed-rank } \\
\text { test for Cx }\end{array}$ & $N$ & $\begin{array}{l}\text { Wilcoxon signed-rank } \\
\text { test for LAD }\end{array}$ & $N$ & $\begin{array}{l}\text { Wilcoxon signed-rank } \\
\text { test for RCA }\end{array}$ \\
\hline \multirow[t]{5}{*}{ 2D QCA } & 5 & 68 & $<0.001$ & 80 & $<0.001$ & 52 & $<0.001$ \\
\hline & 15 & 68 & 0.03 & 80 & $<0.001$ & 52 & $<0.001$ \\
\hline & 20 & 68 & $<0.001$ & 80 & $<0.001$ & 52 & $<0.001$ \\
\hline & 25 & 34 & 0.05 & 40 & $<0.001$ & 26 & $<0.001$ \\
\hline & 40 & 34 & 0.001 & 40 & $<0.001$ & 26 & $<0.001$ \\
\hline \multirow[t]{5}{*}{ 3D QCA } & 5 & 68 & 0.57 & 80 & 0.13 & 52 & 0.17 \\
\hline & 15 & 68 & $<0.001$ & 80 & 0.20 & 52 & 0.004 \\
\hline & 20 & 68 & $<0.001$ & 80 & 0.48 & 52 & 0.004 \\
\hline & 25 & 34 & 0.002 & 40 & 0.88 & 26 & 0.05 \\
\hline & 40 & 34 & $<0.001$ & 40 & 0.38 & 26 & 0.01 \\
\hline
\end{tabular}




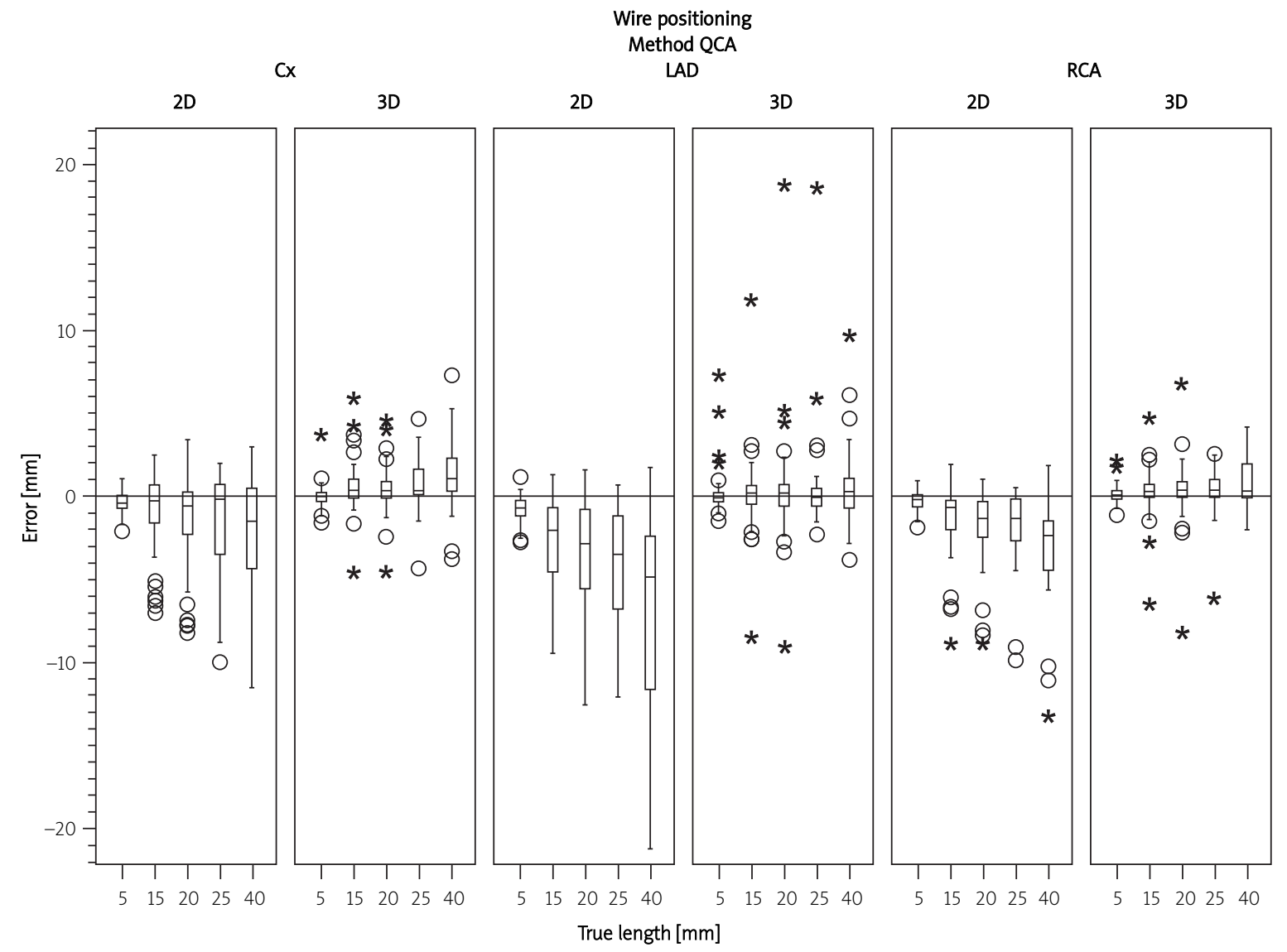

Fig. 4. The accuracy of measurement in 3D QCA presented separately for each studied coronary artery. Boxwhisker plot illustrating differences between measurements and true length in 2D QCA vs. 3D QCA. Horizontal line denotes median value, the height of the box represents the interquartile (25\% to $75 \%$ ) range, and vertical bars show standard deviations. Outliers are shown in circles (values exceeding median $\pm 1.5 \mathrm{SD}$ ) or asterisks (values exceeding median by more than 3 SD)

Ryc. 4. Dokładność pomiarów w 3D QCA pokazana oddzielnie dla każdego odcinka badanej tętnicy. Wykres ilustrujący różnice pomiędzy rzeczywistą długością odcinka a pomiarami w 2D QCA vs 3D QCA. Pozioma linia oznacza średnia wartość, wysokość pudetka reprezentuje przedziat międzykwartylowy (od 25\% do 75\%), a pionowe linie pokazują wartość odchylenia standardowego (SD). Wartości oddalone są wyświetlane jako kótka (wartości powyżej mediany $\pm 1,5$ SD) lub gwiazdki (wartości powyżej mediany o więcej niż 3 SD)

cases. Secondly, in some patients the Common Image Point was not aligned between both projections in the original analyses. The Common Image Point is calculated to align 2 projections and can correct for small inaccuracies due to the X-ray system, patient or table movement. The Common Image Point can be manually corrected if necessary. The automatic CIP was improved in CAAS 5.7.1 and the same 2 patients were later reanalyzed, bringing much improved alignment of the Common Image Point and consequently dramatically reducing the originally reported errors in the 3D QCA length measurements. The third reason for large errors was not related to the software performance. Many errors of $>10 \%$ were found in the $5 \mathrm{~mm}$ length subset. This pointed to the limitation of choosing an arbitrary $10 \%$ error margin, which in a $5 \mathrm{~mm}$ length is $0.5 \mathrm{~mm}$ - at the verge of angiographic resolution and also irrelevant clinically $(0.5 \mathrm{~mm}$ error in coronary intervention is negligible).

When inter- and intra-analyst reproducibility (Figures 5 and 6) was calculated we found no significant differences beside one for inter-analysis in 3D QCA length $5 \mathrm{~mm}$ $(p=0.04)$. As noted above, this was likely a serendipitous and isolated finding resulting from the higher propensity for discrepancy when assessing a very short $5 \mathrm{~mm}$ length. Also, it is possible that the small sample size increased the impact of the outlying values on the power of the statistical comparison.

\section{Discussion}

The main findings of the present study are that: (1) three-dimensional reconstruction from standard routine 


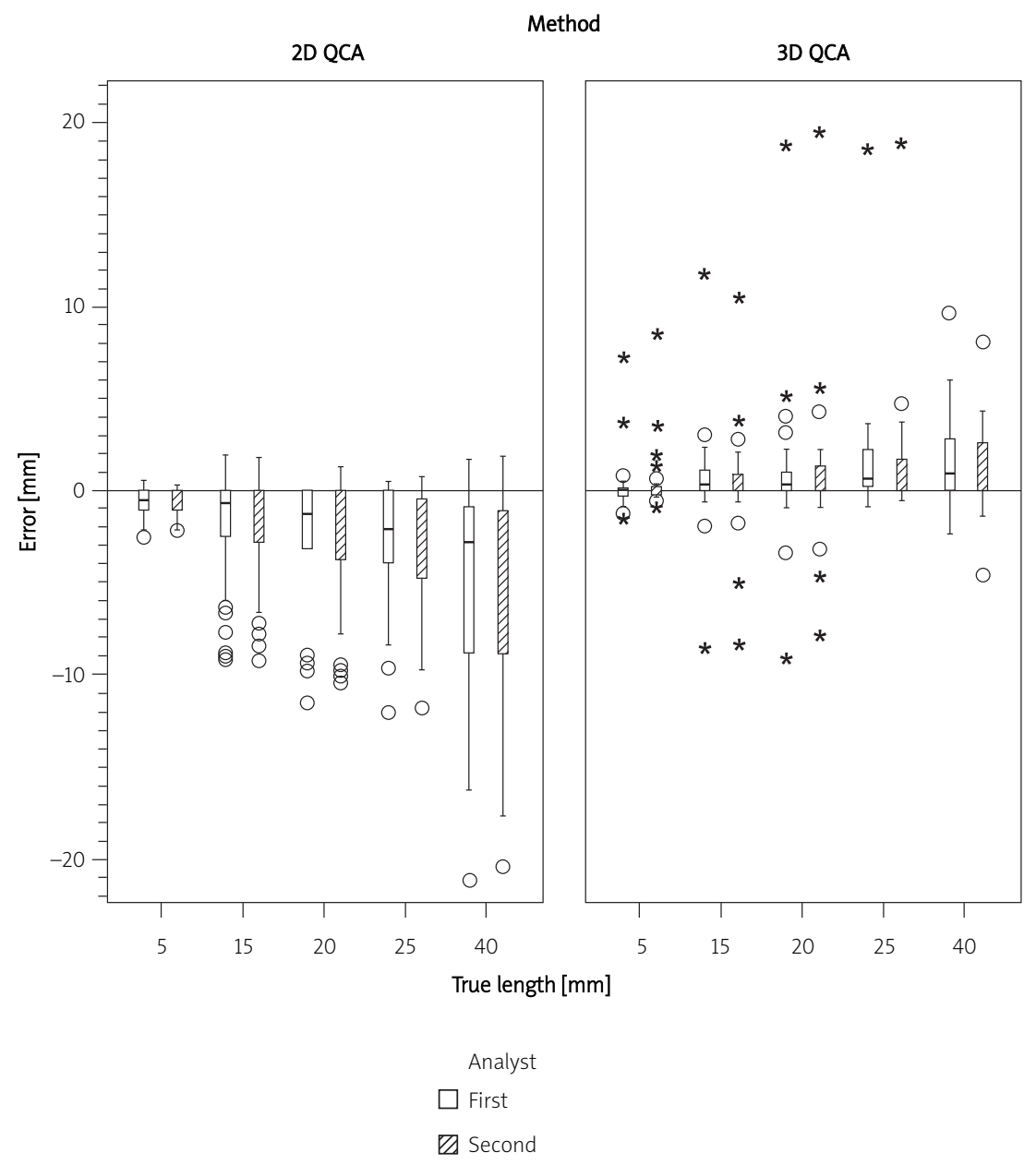

Fig. 5. Differences between length measurements with both methods (2D QCA and 3D QCA) by 2 different analysts (inter-observer variability). Box-whisker plot illustrating differences between measurements and true length in 2D QCA vs. 3D QCA. Horizontal line denotes median value, the height of the box represents the interquartile ( $25 \%$ to $75 \%$ ) range, and vertical bars show standard deviations. Outliers are shown in circles (values exceeding median $\pm 1.5 \mathrm{SD}$ ) or asterisks (values exceeding median by more than $3 \mathrm{SD}$ )

Ryc. 5. Różnice między pomiarami długości z zastosowaniem obu metod (2D QCA i 3D QCA) wykonanymi przez 2 analityków (zmienność pomiędzy obserwatorami). Wykres ilustrujący różnice pomiędzy uzyskanymi wynikami w 2D QCA i 3D QCA w stosunku do prawdziwych długości. Pozioma linia oznacza średnią wartość, wysokość pól reprezentuje przedziat międzykwartylowy (od 25\% do 75\%), zakres i pionowe paski pokazuja odchylenia standardowe (SD). Wartości oddalone są wyświetlane jako kótka (wartości przekraczające medianę $\pm 1,5$ SD) lub gwiazdki (wartości przekraczające średnio o ponad 3 SD)

angiographic images is highly feasible and (2) 3D QCA provides more accurate information on coronary arterial segment length when compared to standard 2D QCA. As such, the present study showed very good reliability and accuracy of a novel 3D QCA modeling system in performing intracoronary length calculations as compared with true intracoronary lengths measured by the marker guidewire and the widely accepted standard 2D QCA. However, it has to be noted that the $2 \mathrm{D}$ results in the present study are worse than normally expected, because half of the measurements were performed in a secondary, suboptimal projection that would otherwise not be used. As such, the dif- ference between 2D and 3D may be unfairly enhanced. Nevertheless, this bias does not diminish the 3D QCA's ability to effectively correct for this shortcoming.

The present study further extends and generally corroborates the recent study, which validated the same 3D QCA system against 3D reconstructions based on fusion of angiography and intravascular ultrasound, allowing slice by slice validation of the lumen areas and 3D geometric values [10]. That study focused primarily on, and successfully demonstrated, adequate precision of stenosis assessment by CAAS 3D QCA. However, the findings in length measurement precision were slightly different from ours: the 3D QCA 


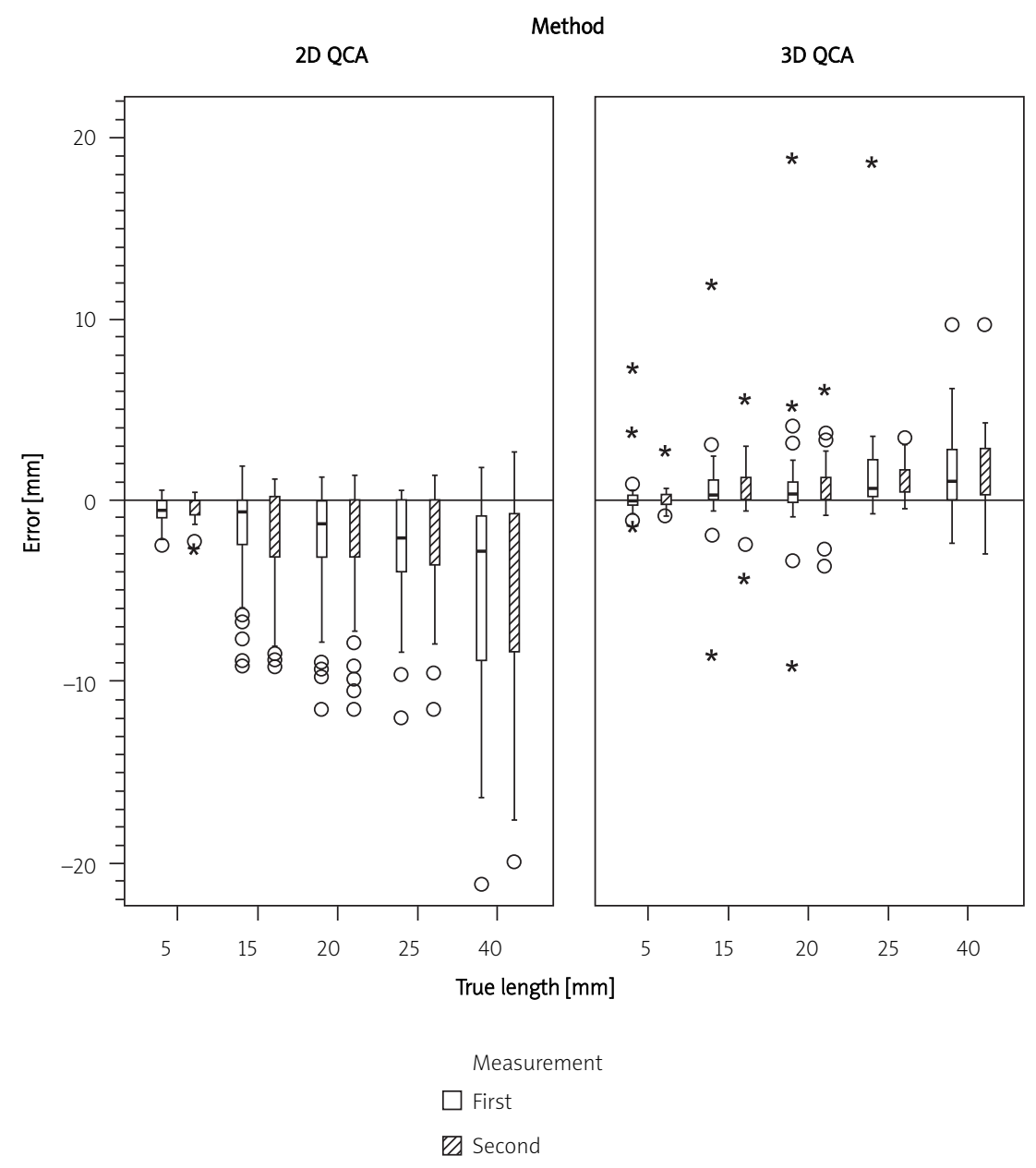

Fig. 6. Differences between lengths measurements for first and second measurement with both methods (2D and 3D QCA) by the same analyst (intra-observer variability). Box-whisker plot illustrating differences between measurements and true length in 2D QCA vs. 3D QCA. Horizontal line denotes median value, the height of the box represents the interquartile (25\% to $75 \%$ ) range, and vertical bars show standard deviations. Outliers are shown in circles (values exceeding median $\pm 1.5 \mathrm{SD}$ ) or asterisks (values exceeding median by more than $3 \mathrm{SD}$ ) Ryc. 6. Różnice pomiędzy wartościami dwóch oddzielnych pomiarów z zastosowaniem obu metod (2D QCA i 3D QCA) wykonanych przez tego samego analityka (zmienność dla pojedynczego obserwatora). Wykres ilustrujący różnice pomiędzy wynikami uzyskanymi w 2D QCA i 3D QCA w stosunku do prawdziwych długości. Pozioma linia oznacza średnia wartość, wysokość pól reprezentuje przedziat międzykwartylowy (od 25\% do 75\%), zakres i pionowe paski pokazują odchylenia standardowe (SD). Wartości oddalone są wyświetlane jako kótka (wartości przekraczające medianę $\pm 1,5$ SD) lub gwiazdki (wartości przekraczające średnio o ponad 3 SD)

slightly underestimated coronary length in that study as opposed to slight overestimation in our analysis. This can be explained by several factors and does not necessarily mean markedly divergent conclusion. First, the benchmarks to which the 3D QCA-generated lengths were compared were markedly different (length generated indirectly from fusion imaging vs. directly measured actual length on the marker wire). Second, we examined a shorter range of lengths: $5-40 \mathrm{~mm}$ vs. $46-78 \mathrm{~mm}$ in that earlier study [10]. Last but not least, there is a difference in method between the two studies that explains the discrepancy very well. In the present study the length of a marker wire is measured.
This marker wire is inside the vessel from which the contours are detected. A wire will always choose the shortest path through the vessel. The centerline (which was also measured with ANGUS) represents the middle of the vessel. Therefore it is expected that CAAS will slightly overestimate the wire length, since the actual route of the wire is different, i.e. shorter than the centerline. Furthermore, the overall conclusions of both studies are in fact concordant: that the differences between the actual and the 3D-QCA measured intracoronary length are minimal (on average ca. $1 \mathrm{~mm}$ error in lengths of $40 \mathrm{~mm}$ and higher in both studies). 
Another study using similar methodology (a marker wire as a benchmark for intracoronary length measurements) showed very similar precision in quantitative evaluation of coronary anatomy as our present study [9]. However, 3D reconstructions in that study were generated from rotational angiography. Thus, it is noteworthy that CAAS 3D QCA renders reliable and precise 3D reconstructions and quantitative data without the need to perform rotational angiography, as it utilizes a combination of conventional angiographic images routinely obtained during everyday diagnostic coronary catheterization.

Reliable assessment of lesion length and the length of the stent (BMS and DES) implanted in order to adequately cover the lesion remains an important clinical issue. It has a significant influence on long-term results of percutaneous coronary interventions, especially in complex and long (> $20 \mathrm{~mm}$ ) lesions. Implantation of a stent of inappropriate length (too short) is associated with higher risk of edge dissection and the phenomenon of "geographical miss", which are responsible for increased risk of restenosis and in-stent thrombosis. On the other hand, excessive length of the stent implanted was also found to correlate with risk of restenosis [12] and stent thrombosis [13-17]. In everyday practice the intracoronary lesion length during the $\mathrm{PCl}$ procedure is assessed with one of three conventional methods, none of which is optimal. Most popular is the use of 2D QCA, which is widely known to be inaccurate due to foreshortening of the segment of interest in the two-dimensional image to a various degree. Another method is the use of a marker guidewire. However, commercially available marker wires are preferably used during simple and uncomplicated procedures as the presence of radiopaque markers may make the assessment of potential dissections difficult. Lastly, intravascular ultrasound (IVUS) is a very useful clinical tool for pre-procedural lesion assessment, but not necessarily for lesion length measurements because automated pullback devices cannot always guarantee stable, linear movement of the IVUS probe and as such may adversely influence the length measurements.

For the reasons outlined above, for years there has been a considerable interest in developing 3-dimensional angiographic reconstruction $[4,5]$ to improve the guidance of $\mathrm{PCl}$ for a variety of purposes (e.g. more precise stent selection, tackling chronic total occlusions, remote or robotic guidance of $\mathrm{PCI}$ ). But only recently have the advances in computer power made simple and fast 3-dimensional rendering of angiographic images possible [6-10]. Three-dimensional angiography proved useful in assessment of one of the most complex interventional challenges, left main coronary anatomy [20]. Recently, a study demonstrated that the majority of the 3D volume images were rated as having high image quality (66\%) and provided the physician with additional clinical information such as complete visualization of bifurcations and unobtainable views of the coronary tree [21]. True-positive lesion detection rates were high ( $90 \%$ to $100 \%)$, whereas false-positive detection rates were low (0 to $8.1 \%$ ). Finally, 3D quantitative coronary analysis showed significant similarity with 2D quantitative coronary analysis in terms of lumen diameters and provided vessel segment length free from the errors of foreshortening. This elegant and comprehensive study, however, necessitated rotational angiography for generation of 3D image reconstructions, whereas today most catheterization laboratories do not have that capability. In contrast, CAAS 3D can be utilized in conjunction with any currently available digital cardiac catheterization angiographic equipment. Most recently, a study examining the relationship between QCA and fractional flow reserve (FFR) concluded that where FFR is not available or contraindicated, 3D-QCA may assist in the evaluation of coronary lesions of intermediate severity [22].

\section{Conclusions}

Our study provides additional evidence based on actual patient imaging that three-dimensional coronary modeling is highly feasible and yields more accurate assessments of the lengths of coronary segments than standard two-dimensional QCA over a wide range of lengths.

\section{References}

1. Foley DP, Escaned J, Strauss BH, et al. Quantitative coronary angiography (QCA) in international cardiology: clinical application of QCA measurements. Prog Cardiovasc Dis 1994; 36: 363-384.

2. Green NE, Chen SY, Messenger JC, et al. Three-dimensional vascular angiography. Curr Probl Cardiol 2004; 29: 104-142.

3. Herrington DM, Siebes M, Sokol DK, et al. Variability in measures of coronary lumen dimensions using quantitative coronary angiography. J Am Coll Cardiol 1993; 22: 1068-1074.

4. Wellnhofer E, Wahle A, Mugaragu I, et al. Validation of an accurate method for three-dimensional reconstruction and quantitative assessment of volumes, lengths and diameters of coronary vascular branches and segments from biplane angiographic projections. Int J Card Imaging 1999; 15: 339-353.

5. Messenger JC, Chen SY, Carroll JD, et al. 3D coronary reconstruction from routine single-plane coronary angiograms: clinical validation and quantitative analysis of the right coronary artery in 100 patients. Int J Card Imaging 2000; 16: 413-427.

6. Dvir D, Marom H, Guetta V, Kornowski R. Three-dimensional coronary reconstruction from routine single-plane coronary angiograms: in vivo quantitative validation. Int J Cardiovasc Intervent 2005; 7: 141-145.

7. Gradaus R, Mathies K, Breithardt G, Böcker D. Clinical assessment of a new real time 3D quantitative coronary angiography system: evaluation in stented vessel segments. Catheter Cardiovasc Interv 2006; 68: 44-49.

8. Ramcharitar S, Daeman J, Patterson M, et al. First direct in vivo comparison of two commercially available three-dimensional quantitative coronary angiography systems. Catheter Cardiovasc Interv 2008; 71: 44-50.

9. Agostoni P, Biondi-Zoccai G, Van Langenhove G, et al. Comparison of assessment of native coronary arteries by standard versus 
three-dimensional coronary angiography. Am J Cardiol 2008; 102: 272-279.

10. Schuurbiers JC, Lopez NG, Ligthart J, et al. In vivo validation of CAAS QCA-3D coronary reconstruction using fusion of angiography and intravascular ultrasound (ANGUS). Catheter Cardiovasc Interv 2009; 73: 620-626.

11. Green NE, Chen SY, Hansgen AR, et al. Angiographic views used for percutaneous coronary interventions: a three-dimensional analysis of physician-determined vs. computer-generated views. Cathet Cardiovasc Interv 2005; 64: 451-459.

12. Sakurai R, Ako J, Morino Y, et al.; SIRIUS Trial Investigators. Predictors of edge stenosis following sirolimus-eluting stent deployment (a quantitative intravascular ultrasound analysis from the SIRIUS trial). Am J Cardiol 2005; 96: 1251-1253.

13. Fujii K, Carlier SG, Mintz GS, et al. Stent underexpansion and residual reference segment stenosis are related to stent thrombosis after sirolimus-eluting stent implantation: an intravascular ultrasound study. J Am Coll Cardiol 2005; 45: 995-998.

14. Park DW, Park SW, Park KH, et al. Frequency of and risk factors for stent thrombosis after drug-eluting stent implantation during long-term follow-up. Am J Cardiol 2006; 98: 352-356.

15. Okabe T, Mintz GS, Buch AN, et al. Intravascular ultrasound parameters associated with stent thrombosis after drug-eluting stent deployment. Am J Cardiol 2007; 100: 615-620.

16. Baran KW, Lasala JM, Cox DA, et al.; ARRIVE Investigators. A clinical risk score for prediction of stent thrombosis. Am J Cardiol 2008; 102: 541-545.

17. Liu X, Doi H, Maehara A, et al. A volumetric intravascular ultrasound comparison of early drug-eluting stent thrombosis versus restenosis. JACC Cardiovasc Interv 2009; 2: 428-434.

18. Gronenschild E, Janssen J, Tijdens F. CAAS. II: A second generation system for off-line and on-line quantitative coronary angiography. Cathet Cardiovasc Diagn 1994; 33: 61-75.

19. Tommasini G, Rubartelli P, Piaggio M. A deterministic approach to automated stenosis quantification. Catheter Cardiovasc Interv 1999; 48: 435-445.

20. Girasis C, Serruys PW, Onuma Y, et al. 3-Dimensional bifurcation angle analysis in patients with left main disease: a substudy of the SYNTAX trial (SYNergy Between Percutaneous Coronary Intervention with TAXus and Cardiac Surgery). JACC Cardiovasc Interv 2010; 3: 41-48.

21. Neubauer AM, Garcia JA, Messenger JC, et al. Clinical feasibility of a fully automated $3 \mathrm{D}$ reconstruction of rotational coronary $\mathrm{X}$-ray angiograms. Circ Cardiovasc Interv 2010; 3: 71-79.

22. Yong AS, Ng AC, Brieger D, et al. Three-dimensional and twodimensional quantitative coronary angiography, and their prediction of reduced fractional flow reserve. Eur Heart J 2011; 32: 345-353. 